\title{
SISTEM KENDALI OTOMATIS PROTOTYPE ROBOT MOBIL UNTUK PARKIR PINTAR MENGGUNAKAN KOMUNIKASI NIRKABEL
}

\author{
I Gede Pande Mastra Sedana ${ }^{1}$, Ngurah Indra ER ${ }^{2}$ Linawati $^{3}$
}

\begin{abstract}
Robotics technology have evolve rapidly to assist society using machines according to the needs. The basic purpose of robotics technology development is to help human on certain task which need high accuracy, risky, or jobs with repetition. One robotics technology application that closely related to control system is prototyping of Car Robot Automatic System for Smart Parking implementing Wireless Communication. The system used HC-05 Bluetooth based on ATmega32 microcontroller controlling system. HC-05 Bluetooth acted as wireless communication media that connect the car robots and the smartphone. ATmega32 microcontroller on the robot receive inputs from range sensor, line sensor, push button, and smartphone. The processed result of the car robot microcontroller transmit back to the smartphone, and the microcontroller on the car robot controlled the motor driver so the DC motor and the wheels on the car robot moved. The final result achieved in this research are wireless communication system that can control the movement of the car robot, read ranges of the front, left and right side, read the value of the line sensor, move forward, backward, turn left and right according to the sensor data. This movement by the car robot can be execute manually and also automatically
\end{abstract}

Intisari-Teknologi robotika berkembang pesat untuk membantu kerja masyarakat dengan mesin sesuai kebutuhan. Sesuai tujuan dasar dari pengembangan teknologi robotika yaitu untuk membantu manusia dalam mengerjakan pekerjaan yang membutuhkan keakuratan tinggi, memiliki resiko tinggi, dan pekerjaan yang dilakukan berulang-ulang. Salah satu aplikasi teknologi robotika yang berhubungan dengan sistem kontrol adalah prototype dari sistem kendali otomatis robot mobil untuk parkir pintar menggunakan komunikasi nirkabel. Sistem in menggunakan bluetooth $\mathrm{HC}-05$ berbasis sistem kontrol ATmega32. Bluetooth HC-05 bertindak sebagai media komunikasi nirkabel yang menghubungkan robot mobil dengan smartphone. Sistem kontrol Atmega32 pada robot mobil menerima data input melalui sensor jarak, sensor garis, tombol dan smartphone. Hasil yang telah diproses pada sistem kontrol robot mobil ditransmisikan kembali ke smartphone. Sistem kontrol pada robot mobil dapat mengendalikan driver motor sehingga motor dc berputar dan robot mobil bergerak. Hasil akhir yang dicapai melalui penelitian ini adalah sistem komunikasi nirkabel yang dapat mengkontrol pergerakan pada robot mobil, membaca jarak pada sisi depan robot mobil, kiri dan kanan, membaca nilai dari sensor garis robot mobil, bergerak maju, mundur, berbelok ke kiri dan kanan sesuai

${ }^{1}$ Mahasiswa Jurusan Teknik Elektro dan Komputer Fakultas Teknik, Universitas Udayana, Br. Dinas Bajera Kelod Jalan Glogor No 11 Tabanan 82162 Indonesia. Tlp : 081353304987, (e-mail: pandemastra@gmail.com)

2,3 Dosen Jurusan Teknik Elektro dan Komputer Fakultas Teknik Universitas Udayana, (telp/fax: 0361-703315; e-mail: ngurah.indra.er@gmail.com,linawati@unud.ac.id) dengan data yang diterima sensor. Pergerakan dari robot mobil dapat diatur baik secara manual maupun otomatis.

Kata Kunci-prototype parkir pintar, robot mobil, mikrokontroler, ATmega32, Bluetooth HC-05.

\section{Pendahuluan}

Teknologi robotika berkembang dengan sangat pesat, dimana kehidupan masyarakat sangat banyak di bantu dengan hadirnya robot yang dapat dipekerjakan sesuai dengan kebutuhan. Utamanya dalam industri bidang otomotif yang dapat melakukan pengembangan aplikasi robotika. Oleh karenanya timbul ide untuk mengembangkan teknologi terutama di bidang robotika, yakni robot mobil nirkabel.

Perkembangan teknologi pada smartphone juga sangat pesat, dimana berbagai aplikasi yang terdapat di dalamnya dapat diaplikasikan pada bidang robotika, khususnya teknologi telekomunikasi nirkabel. Komunikasi nirkabel adalah sistem komunikasi pada suatu jaringan yang menggunakan gelombang radio sebagai media transmisi.

Robot mobil pada umumnya telah dapat dikendalikan menggunakan remote control (RC) secara nirkabel, namun tidak dilengkapi dengan fungsi deteksi jarak penghalang disekitarnya.

Deteksi jarak terhadap penghalang merupakan fungsi penting yang harus dimiliki untuk dapat bergerak, mengetahui adanya penghalang, menghindari, dan bergerak ke posisi yang diinginkan. Untuk mencapai kemampuan tersebut maka akan diintegrasikan sistem kontrol ATmega32 dengan sensor jarak, bluetooth, sensor garis, dan motor driver pada robot mobil.

Selanjutnya akan diintegrasikan pula software pada smartphone yang digunakan sebagai pengendali pengganti remote control biasa, yang juga berfungsi sebagai sarana komunikasi dengan robot mobil. Smartphone dapat digunakan sebagai sarana kendali posisi dari robot mobil untuk mencari posisi parkir dan dapat menjadi sarana komunikasi data yang dapat dilakukan melalui smartphone.

Akhirnya akan diperlihatkan bagaimana kinerja sistem parkir pintar yang telah diintegrasikan pada robot mobil ditinjau dari akurasi posisi ketika sistem dikendalikan secara manual maupun otomatis.

Robot mobil merupakan aplikasi yang dirancang agar tercipta suatu sistem parkir pintar yang memanfaatkan sensor dengan menggunakan komunikasi nirkabel bluetooth series HC-05 berbasis sistem kontrol ATmega32. Perangkat bluetooth series HC-05 nantinya akan bertindak sebagai media komunikasi nirkabel yang mengirimkan data dari smartphone sesuai dengan instruksi menuju ke rangkaian robot mobil (transciever). 
Diharapkan hasil penelitian sistem parkir pintar robot mobil dengan memanfaatkan sensor jarak dan menggunakan komunikasi Bluetooth Series HC-05 berbasis sistem kontrol ATmega32 ini, dapat digunakan untuk mengendalikan robot mobil dalam pengambilan posisi pada tempat yang sulit dijangkau oleh mata manusia. Pengambilan posisi ini bisa berupa posisi parkir di tempat yang sempit pada suatu ruangan.

\section{KAJIAN PUSTAKA}

\section{A. State of The Art Review}

Penelitian tentang robot mobil saat ini telah banyak dilakukan, terutama yang berkaitan dengan perancangan perangkat keras serta metode pergerakan pada robot mobil. Namun, dari penelitian tersebut belum ada yang melakukan penelitian mengenai pengembangan pengendalian pergerakan robot mobil yang secara mudah dapat dilakukan oleh setiap orang, karena sebagian besar robot mobil saat ini dikendalikan dengan menggunakan remote control atau kendali secara otomatis. Melalui penelitian mengenai prototype sistem kendali otomatis robot mobil untuk parkir pintar menggunakan komunikasi nirkabel, diharapkan mampu untuk mempermudah mengendalikan pergerakan dari robot mobil pada saat menelusuri ruangan. Berikut ini beberapa referensi yang dapat dijadikan acuan dalam menjelaskan mengenai penelitian tentang prototype sistem kendali otomatis robot mobil.

1. Pada penelitian yang dilakukan oleh B.Ranga Raju yang di publish pada sebuah jurnal penelitian dari Sri Vasavi Engineering College, Tadepalligudem, India pada tahun 2014 yang berjudul "ARM7 Microcontroller based Robot controlled by an Android mobile utilizing Bluetooth", diperoleh bahwa dalam penelitian ini penulis menggunakan remote control dari android yang berfungsi untuk kendali wireless pada mobile robot sehingga memungkinkan mobile robot mampu menerima perintah melalui android. [6].

2. Pada penelitian yang dilakukan oleh Ritika Pahuja yang di publish pada sebuah jurnal penelitian dari BRCM College of Engineering \& Technology, Bahal, India pada tahun 2014 yang berjudul "Android Mobile Phone Controlled Bluetooth Robot Using 8051 Microcontroller", diperoleh bahwa dalam penelitian ini penulis menggunakan bluetooth HC series sebagai receiver dan pada smartphone digunakan Software Bluetooth RC Control yang sudah dapat di download secara langsung di appstore yang berfungsi untuk kendali wireless mobil robot [10].

\section{B. Mikrokontroler}

ATmega32 merupakan jenis mikrokontroler AVR CMOS 8-bit berbasis arsitektur AVR RISC (Reduced Intrution Set Computer). AVR juga mempunyai In-System Programmable Flash on-chip yang mengijinkan memori program untuk diprogram ulang dalam sistem menggunakan hubungan serial SPI [4].

ATmega32 mempunyai empat buah port yaitu Port.A, Port.B, Port.C, dan Port.D.mKonfigurasi pin mikrokontroler
ATmega32 dengan kemasan 40-pin DIP (dual inline package) ditunjukkan pada Gambar 1.

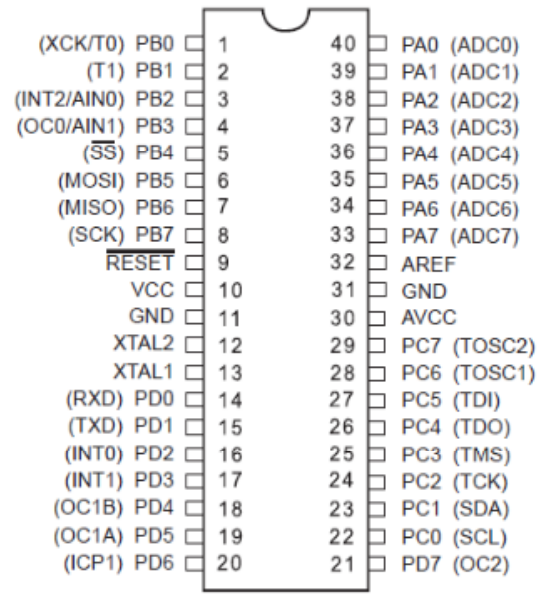

Gambar 1: Konfigurasi pin Atmega32 [5]

1) Komunikasi Serial USART: USART singkatan dari (Universal Syncronous Asyncronous Receiver / Transmiter). Mikrokontroler ATmega32 memiliki kelebihan sistem USART yaitu :

- Operasi full duplex (mempunyai register receiver dan transmitter yang terpisah).

- Operasi Syncronous dan Asyncronous.

- Medukung komunikasi multi prosesor.

- Mode kecepatan transmisi data berorde Mbps. [1]

\section{Regulator}

IC Regulator atau yang sering disebut sebagai regulator tegangan (voltage regulator) merupakan suatu komponen elektronik yang melakukan suatu fungsi yang terpenting dan berguna dalam perangkat elektronik baik digital maupun analog. Konfigurasi pin regulator $78 x x$ ditunjukkan pada gambar 2.

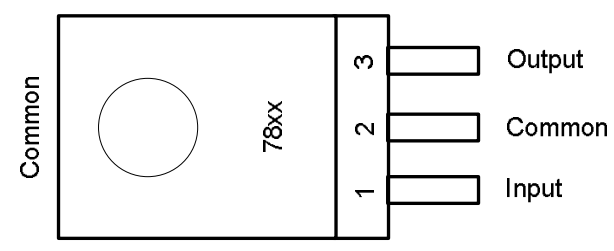

Gambar 2: Ilustrasi konfigurasi pin IC Regulator 78xx

Regulator 7805 \& 7809 memerlukan tegangan positif dengan tiga terminal masing-masing terminal input, terminal output dan terminal ground. Tegangan yang akan diregulasi diberikan pada terminal input dan ground [4].

\section{LCD Display Module}

LCD Display Module M1632 terdiri dari dua bagian, yang pertama merupakan panel $L C D$ sebagai media penampil informasi dalam bentuk huruf/angka, yang dapat menampung 16 huruf/angka di setiap baris. Bagian kedua merupakan sistem pengontrol panel $L C D$, yang berfungsi mengatur tampilan informasi serta berfungsi mengatur komunikasi 
M1632 dengan mikrokontroler [5]. Konfigurasi pin 16x2 LCD ditunjukkan pada Gambar 3.

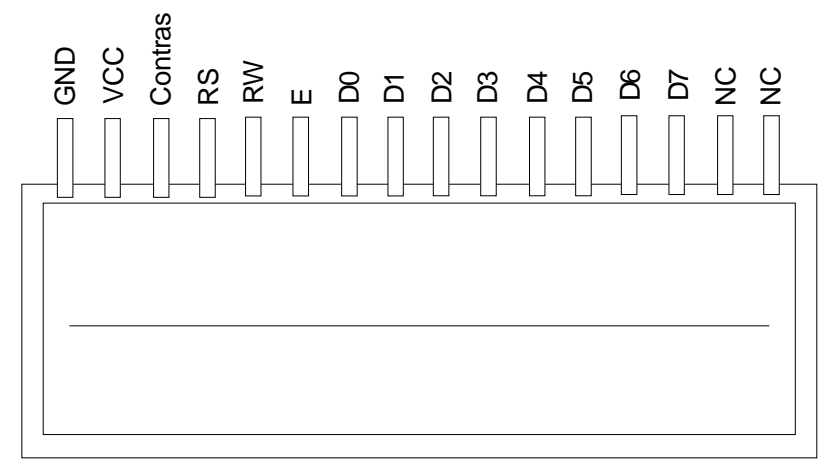

Gambar 3: Ilustrasi LCD modul M1632

\section{E. Push Button}

Push button pada robot mobil berfungsi sebagai perantara fisik dalam memberikan inputan untuk mengendalikan robot mobil. Push button digunakan untuk memberikan perintah kepada mikrokontroler dengan membedakan nilai tegangan pada pin input mikrokontroler.

Ketika push button ditekan maka nilai tegangan akan menjadi 0V dan ketika push button tidak ditekan maka nilai tegangan yang didapatkan akan menjadi $5 \mathrm{~V}$. Ilustrasi ditunjukan pada Gambar 4.

\section{Ditekan}

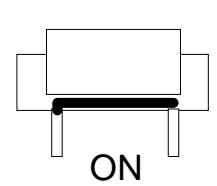

\section{Tidak Ditekan}

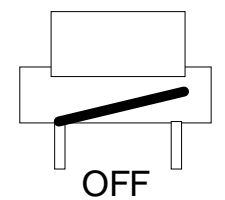

Gambar 4: Ilustrasi push button

\section{F. Modul H-Bridbge L293D}

Modul H-Bridge berbasis L293D di disain untuk menghasilkan dua arah putaran $C W$ (clock wise) maupun $C C W$ (counter clock wise), dengan arus kontinyu sampai dengan 3 A pada rentang tegangan $5 \mathrm{~V}_{\mathrm{DC}}$ sampai $36 \mathrm{~V}_{\mathrm{DC}}$. Selain itu modul ini dilengkapi dengan rangkaian sensor arus beban yang dapat digunakan sebagai umpan balik ke pengendali. Modul ini mampu mengontrol beban induktif seperti relay, solenoida, dan motor DC [7]. Ilustrasi L293D ditunjukan oleh Gambar 5.

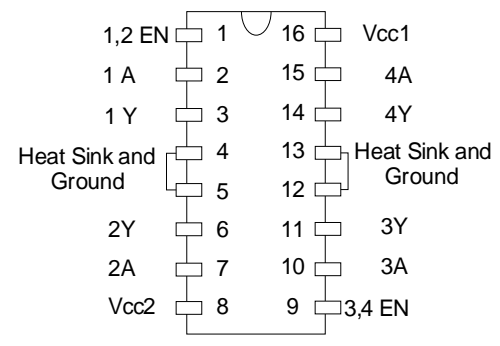

Gambar 5: Ilustrasi pin L293D

\section{G. Sensor Garis}

Untuk membedakan lokasi parkir yang kosong dan jalan yang harus dilalui, maka dapat dilakukan pendeteksian dengan menggunakan sensor garis photodiode yang dipasang pada bagian bawah robot. Sensor ini berfungsi untuk dapat membedakan warna jalur yang berada di bawah robot.

Sensor ini menggunakan lampu led yang akan memancarkan cahaya dan photodiode yang akan mendeteksi pantulan cahaya dari lampu led tersebut seperti pada Gambar 6.

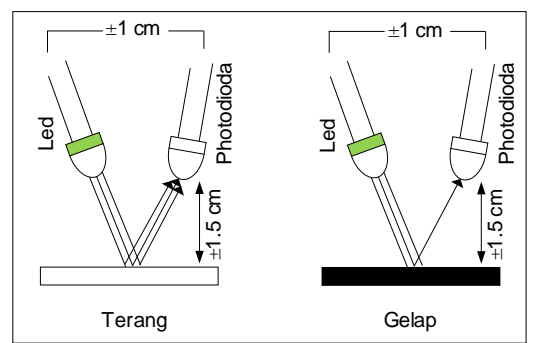

Gambar 6: Ilustrasi pembacaan pantulan cahaya dari sensor garis

\section{H. Sensor Jarak SRF04}

Sensor ini memerlukan 2 pin I/O untuk berkomunikasi dengan mikrokontroler, yaitu Trigger dan Echo. Untuk mengaktifkan SRF04 mikrokontroler mengirimkan pulsa positif melalui pin Trigger minimal $10 \mu$ s, selanjutnya SRF04 akan mengirimkan pulsa positif melalui pin Echo selama 100 $\mu$ s hingga $18 \mathrm{~ms}$, yang sebanding dengan jarak obyek. Dibandingkan dengan sensor ultrasonik lain, seperti PING, SRF04 mempunyai kemampuan yang setara, yaitu rentang pengukuran antara $3 \mathrm{~cm}-3 \mathrm{~m}$, dan output yang sama, yaitu panjang pulsa. Meski cara pengoperasiannya juga mirip, namun kedua sensor tersebut berbeda jumlah pin I/O-nya, yaitu 2 untuk SRF04 dan 1 untuk PING. Ilustrasi bentuk fisik dari modul SRF-04 ditunjukkan pada Gambar 7.

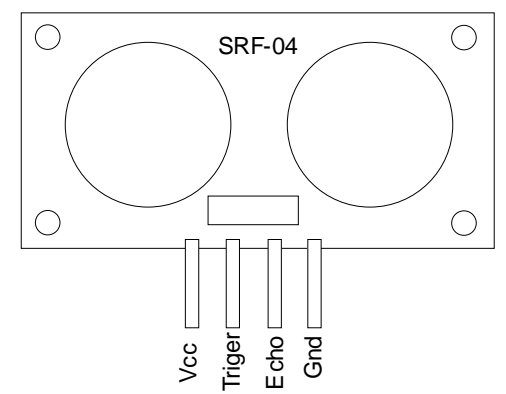

Gambar 7: Bentuk fisik sensor infrared [8]

\section{Rangkaian Sounder}

Rangkaian sounder berfungsi untuk memberikan tanda dalam bentuk suara pada robot mobil. Tanda diberikan pada kondisi tertentu yang di inginkan oleh user yang sudah di program pada robot mobil. Ilustrasi rangkaian sounder dapat dilihat pada Gambar 8. 


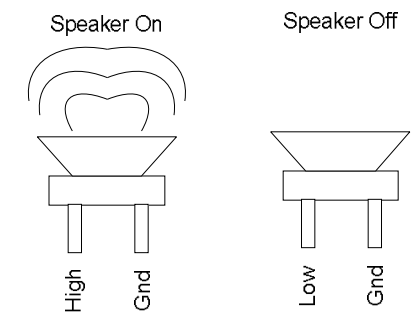

Gambar 8: Ilustrasi rangkaian sounder

\section{J. Bluetooth}

Bluetooth adalah sebuah teknologi komunikasi nirkabel (tanpa kabel) yang beroperasi dalam pita frekuensi $2,4 \mathrm{GHz}$ unlicensed ISM (Industrial, Scientific and Medical) dengan menggunakan sebuah frequency hopping transceiver yang mampu menyediakan layanan komunikasi data dan suara secara real-time antara host-host bluetooth dengan jarak jangkauan layanan yang terbatas.

1) Modul Wireless Bluetooth: Bluetooth HC-05 merupakan modul wireless yang beroperasi pada 2,4 GHz. Modul wireless Bluetooth $\mathrm{HC}-05$ memerlukan catu daya $3,3 \mathrm{~V}_{\mathrm{DC}}$, arus rata-rata $25 \mathrm{~mA}$, daya $\mathrm{RF}=+4 \mathrm{dBm}$ dengan jangkauan jarak 10 meter. Bentuk fisik dari modul wireless Bluetooth HC-05 ditunjukkan pada Gambar 9.
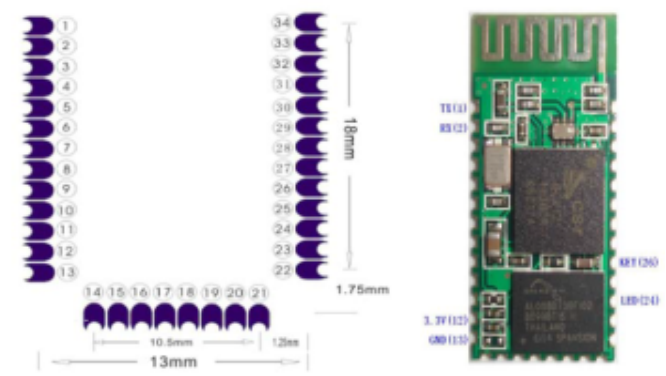

Gambar 9: Modul wireless bluetooth HC-05

Tabel 1 merupakan fungsi dari masing-masing pin I/O pada modul wireless Bluetooth HC-05.

TABEL I

FUNGSI PIN I/O MODUL BLUETOOTH HC-05

\begin{tabular}{|c|c|c|c|c|}
\hline No & Pin & Name & Direction & Description \\
\hline 1 & 12 & VCC & - & Power Supply \\
\hline 2 & 1 & UART_TX & Output & UART Data Out \\
\hline 3 & 2 & UART_Rx & Input & UART Data In \\
\hline 4 & 13,22 & GND & - & Ground \\
\hline 5 & 26 & Key & Input & UART Setting \\
\hline
\end{tabular}

\section{K. Basic Compiler AVR}

Basic Compiler AVR merupakan software C-cross compiler, yaitu program dapat ditulis dalam bahasa basic, Proses download program ke IC mikrokontroler AVR dapat menggunakan system download secara ISP (in-System Programming). [1] software ini bisa di download di situs resmi atmel http://www.mcselec.com/. Gambar 10 merupakan tampilan awal software Basic Compiler AVR.

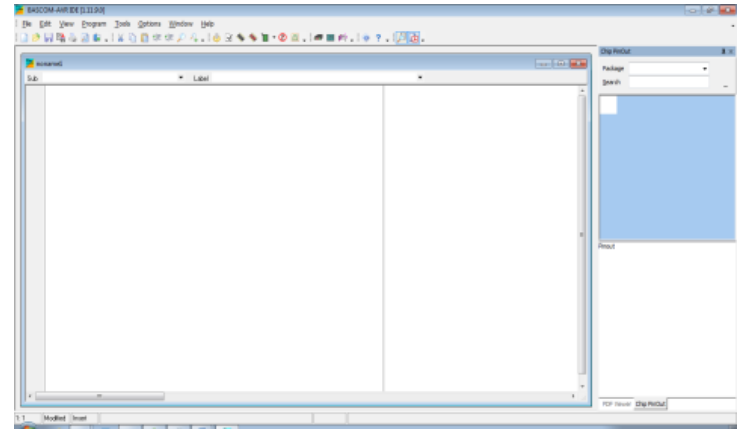

Gambar 10: Tampilan awal software basic compiler AVR [1]

\section{MIT app Inventor}

Kendali robot mobil yang dibuat menggunakan aplikasi online melalui website http://appinventor.mit.edu/explorel dapat diakses untuk keperluan software android. App Inventor adalah sebuah tool untuk membuat aplikasi android yang berbasis visual block programming. Visual block programming maksudnya adalah dalam penggunaannya user akan melihat, menggunakan, menyusun dan drag-drops. Gambar 11 merupakan tampilan awal website untuk untuk mulai membuat aplikasi.

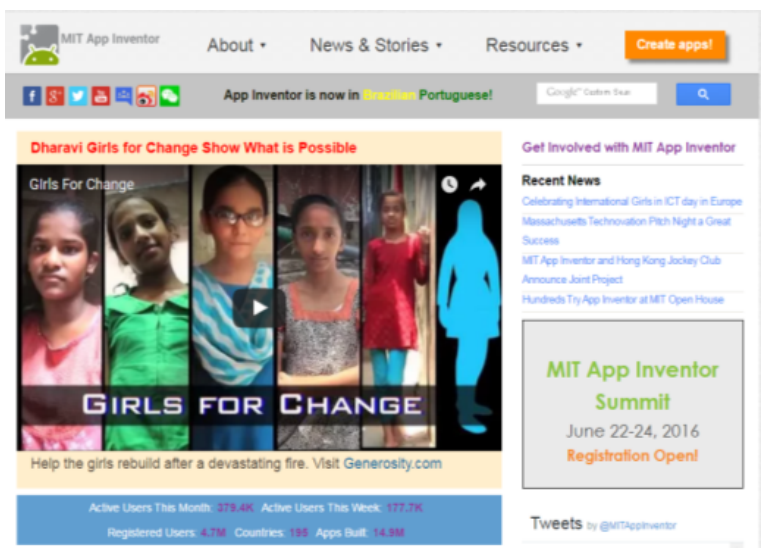

Gambar 11: MIT App Inventor

Project pada situs ini bisa disimpan dan di download sesuai dengan keperluan user yang menggunakannya.

\section{METODE PERANCANGAN}

Metode perancangan prototype sistem kendali otomatis robot mobil untuk parkir pintar menggunakan komunikasi nirkabel terdiri dari perancangan perangkat keras dan perancangan perangkat lunak. Pada perancangan perangkat keras terdiri dari beberapa bagian yaitu:

1. Perancangan rangkaian minimum sistem ATmega32.

2. Perancangan rangkaian regulator

3. Perancangan rangkaian LCD

4. Perancangan rangkaian Push Button

5. Rangkaian modul driver $\mathrm{H}$-Bridge

6. Rangkaian sensor garis

7. Rangkaian sensor jarak

8. Rangkaian sounder 
9. Rangkaian modul Wireless Bluetooth

10. Perancangan Keseluruhan Sistem

Gambar 12 merupakan diagram blok keseluruhan dari prototype sistem kendali otomatis robot mobil untuk parkir pintar menggunakan komunikasi nirkabel.

Gambar 12: Modul wireless bluetooth HC-05

Dalam perancangan Prototype Sistem Kendali Otomatis Robot Mobil untuk Parkir Pintar Menggunakan Komunikasi Nirkabel. Terdapat dua bagian perancangan, yang pertama adalah rangkaian robot mobil (transciever) terdiri dari satu buah system kontrol ATmega32, satu buah Bluetooth HC-05, dua buah motor DC, motor driver H-Bridge, 3 buah sensor jarak HC05, satu buah LCD dan empat buah sensor garis. Kemudian bagian berikutnya adalah smartphone yang berfungsi sebagai transceiver yang di dalamnya telah terinstal software Pande Bluetooth Kontrol yang digunakan untuk mengirimkan dan menerima data, memberikan perintah ke pada robot mobil dan menerima data hasil pembacaan sensor dari robot mobil.

\section{A. Perancangan Rangkaian Minimum Sistem ATMega32}

Perancangan rangkaian minimum sistem merupakan bagian yang terpenting karena sebagai pengendali utama pada robot mobil. Pengendali utama menggunakan IC ATmega32 yang mempunyai empat port utama yaitu port $A$, portB, port $C$ dan portD. Sistem kontrol membutuhkan rangkaian osilator sebagai sumber detak untuk pewaktu internal pada perangkatperangkat internal dari ATmega32. Pin pada XTAL1 dan XTAL2 dihubungkan dengan kristal $12 \mathrm{MHz}$, dan kapasitor C1 dan C2 berfungsi sebagai penstabil detak yang merupakan rekomendasi dari ATMEL.

Pada Prototype Sistem Kendali Otomatis Robot Mobil Untuk Parkir Pintar Menggunakan Komunikasi Nirkabel ini, ATmega32 berfungsi sebagai pengendali dan pengolah data yang diperoleh dari tombol, push button, sensor jarak dan sensor garis yang terhubung ke system kontrol ATmega32 seperti pada Gambar 13.

I Gede Pande Mastra Sedana:Sistem Kendali Otomatis Prototype ...

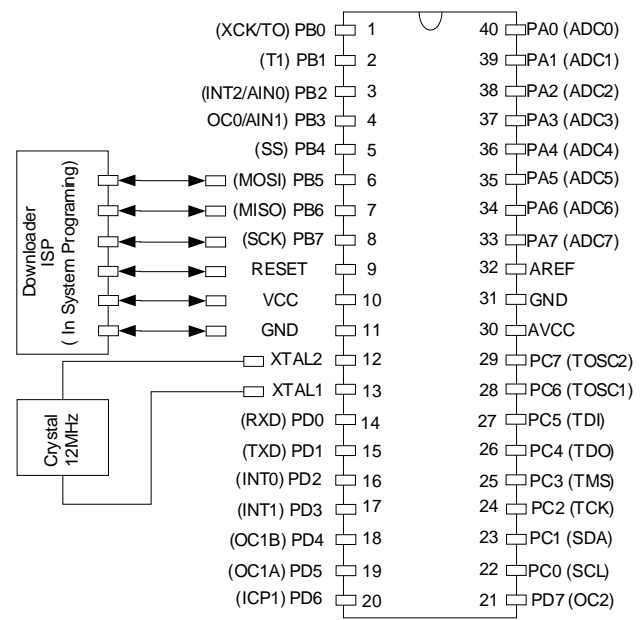

Gambar 13: Perancangan Atmega32 sistem kendali robot mobil

Berikut adalah listing program untuk konfigurasi ATMEGA32.

\begin{tabular}{|c|c|c|}
\hline $\begin{array}{l}\text { \$regfile } \\
\text { \$crystal } \\
\text { \$baud }\end{array}$ & $\begin{array}{l}=" \mathrm{~m} 32 \text { def. dat" } \\
=12000000 \\
=9600\end{array}$ & $\begin{array}{l}\text { ' specify the used micro } \\
\text { ' used crystal frequency } \\
\text {, used baudrate }\end{array}$ \\
\hline
\end{tabular}

\section{B. Perancangan Regulator Robot Mobil}

Rangkaian regulator 7805 berfungsi untuk menurunkan level tegangan menjadi $+5 \mathrm{~V}$ DC dan rangkaian regulator 7809 berfungsi untuk menurunkan level tegangan menjadi +9V DC seperti pada Gambar 14.

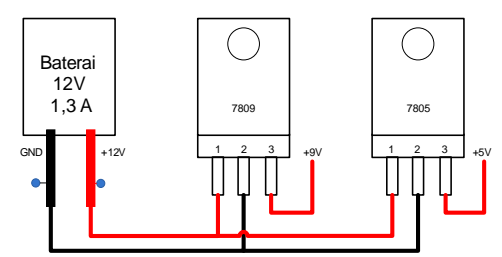

Gambar 14: Perancangan regulator robot mobil

\section{Perancangan LCD Display Robot Mobil}

Perancangan rangkaian LCD (Liquid Crystal Display) menggunakan LCD jenis M1632 yang merupakan LCD 16x2, yaitu 2 baris yang terdiri dari 16 kolom. LCD ini digunakan untuk menampilkan data-data yang dikirim dan yang diterima. Secara garis besar, pada LCD terdapat 16 pin I/O, dimana $R S$, R/W dan E merupakan pin kontrol pada LCD, pin DB4-DB7 merupakan jalur data 4 bit yang akan digunakan dan terhubung pada digital input-output pada minimum sistem ATmega32 seperti pada Gambar 15.

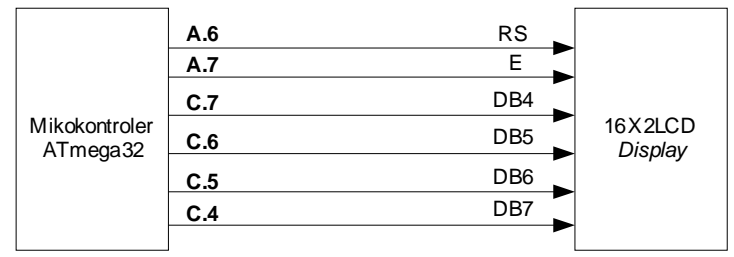

Gambar 15: Perancangan LCD display robot mobil

p-ISSN:1693 - 2951; e-ISSN: 2503-2372 
Berikut adalah listing program untuk menguji LCD.

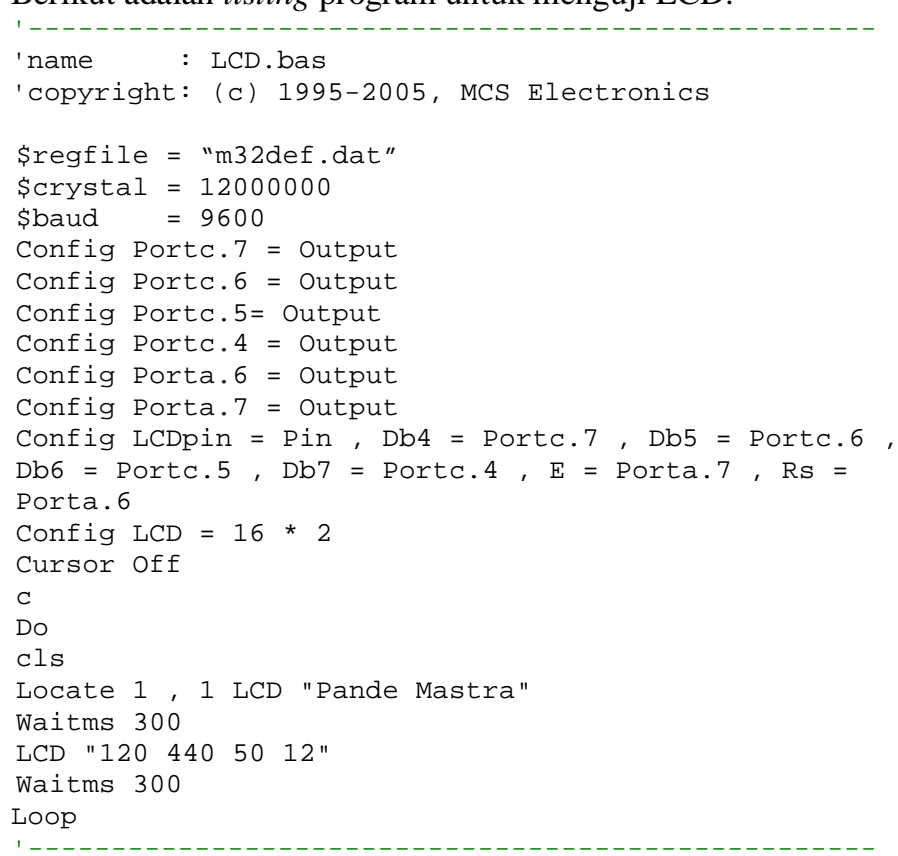

\section{Perancangan Push Button Robot Mobil}

Tombol push button akan dihubungkan ke PINA.5 dan PINB.4 terhadap ground, PINA.5 dan PINB.4 merupakan pin I/O pada system kontrol AVR ATmega32. Perintah dari push button ini diolah untuk menjadi data inputan, misalnya pada saat push button ditekan maka pin I/O pada ATmega32 akan mendeteksi tegangan dibawah $+3.5 \mathrm{~V}$, sebaliknya jika tidak di tekan maka pin I/O akan mendeteksi tegangan $+5 \mathrm{~V}$. Ilustrasi Push button pada pin B.4 seperti pada Gambar 16.
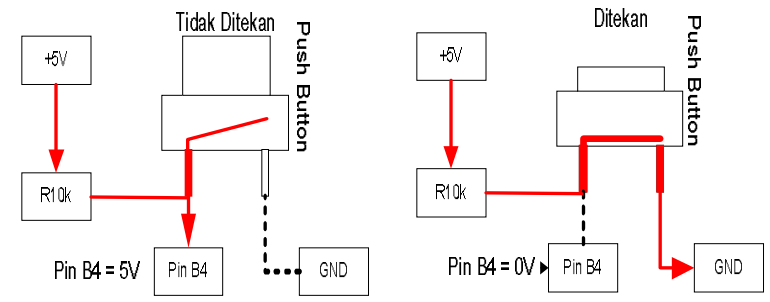

Gambar 16: Perancangan push button robot mobil

Berikut adalah listing program untuk pengujian push button.

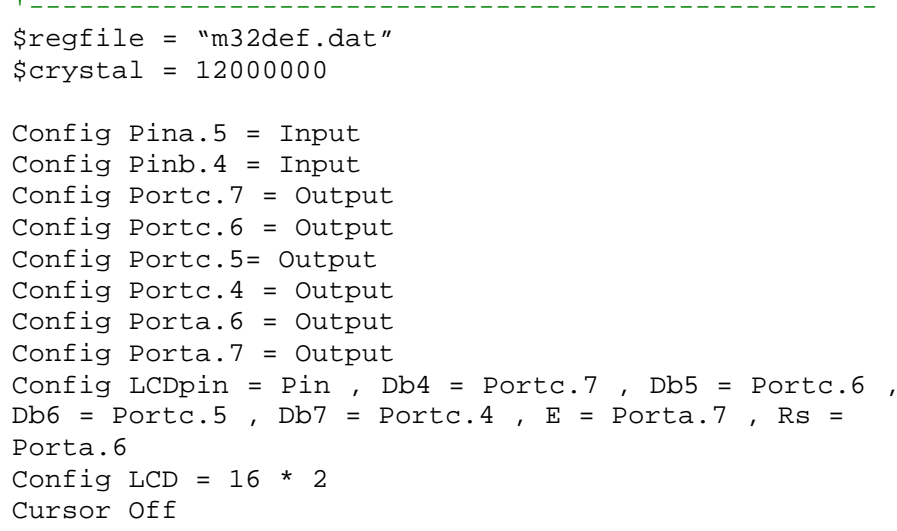

Cursor Off

Swl Alias Pina. 5

Sw2 Alias Pinb. 4

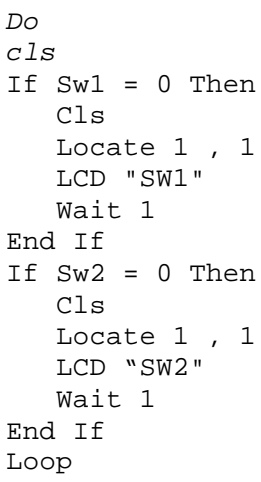

\section{E. Perancangan Modul Driver H-Bridge Robot Mobil}

Rangkaian modul driver H-Bridge pada penelitian ini menggunakan sebuah modul driver $\mathrm{H}$-Bridge berbasis IC L293D, dimana modul driver $\mathrm{H}$-Bridge ini dapat men-driver arus kontinyu maksimal 1 Amper dan tegangannya dari 5.5 $\mathrm{V}_{\mathrm{DC}}$ s/d $36 \mathrm{~V}_{\mathrm{DC}}$. Dapat dilihat pada Gambar 17 adalah interface modul H-Bridge.

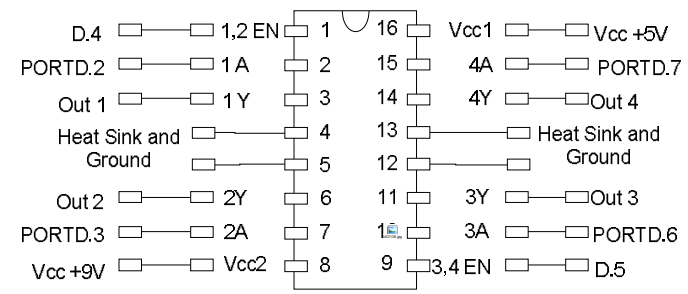

Gambar 17: Perancangan motor driver L293D dengan robot mobil

Berikut adalah listing program untuk menguji modul driver $\mathrm{H}-$ Bridge.

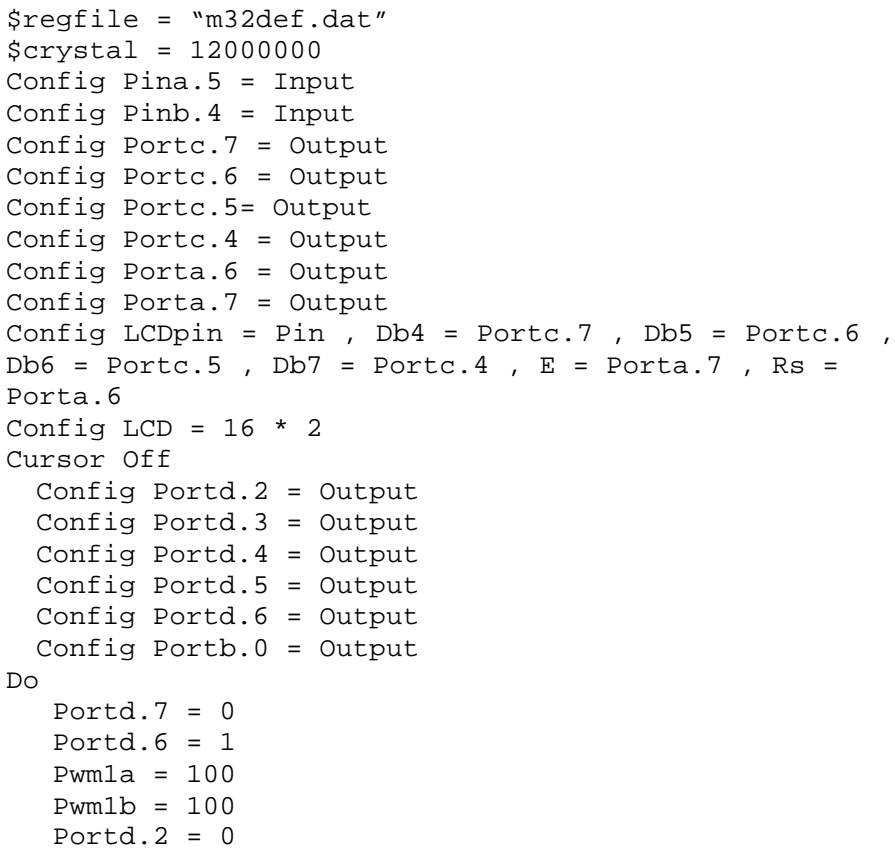


Waitms 30

Loop

\section{F. Perancangan Sensor Garis Robot Mobil}

Untuk membedakan tempat parkir yang kosong dan mengetahui jalan yang harus dilalui, maka dapat dilakukan pendeteksian dengan menggunakan sensor garis photodioda yang digunakan sebanyak 4 buah. Sensor ini berfungsi untuk dapat membedakan warna jalur yang berada di bawah robot, perancangan sensor seperti pada Gambar 18
Portd. $3=1$

Stop Adc

End Sub

\section{G. Perancangan Sensor Jarak Robot Mobil}

SRF04 jenis ini mempunyai catu daya input sebesar $5 \mathrm{~V}_{\mathrm{DC}}$ dengan arus maksimal $100 \mathrm{~mA}$, dengan jarak jangkauan yang bisa diatur mulai dari $3 \mathrm{~cm}$ sampai dengan $300 \mathrm{~cm}$. Pada Gambar 19 merupakan gambar SRF04 ilustrasi.
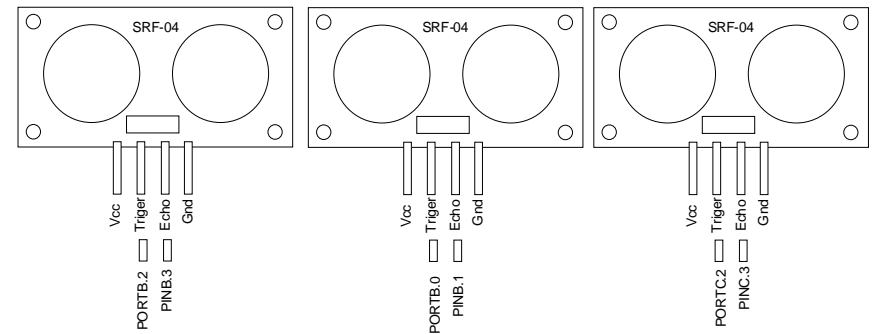

Gambar 19: Perancangan sensor jarak robot mobil

Gambar 18: Perancangan sensor garis robot mobil

Listing program, deklarasi, dan cara akses sensor garis photodiode dapat dilihat sebagai berikut.

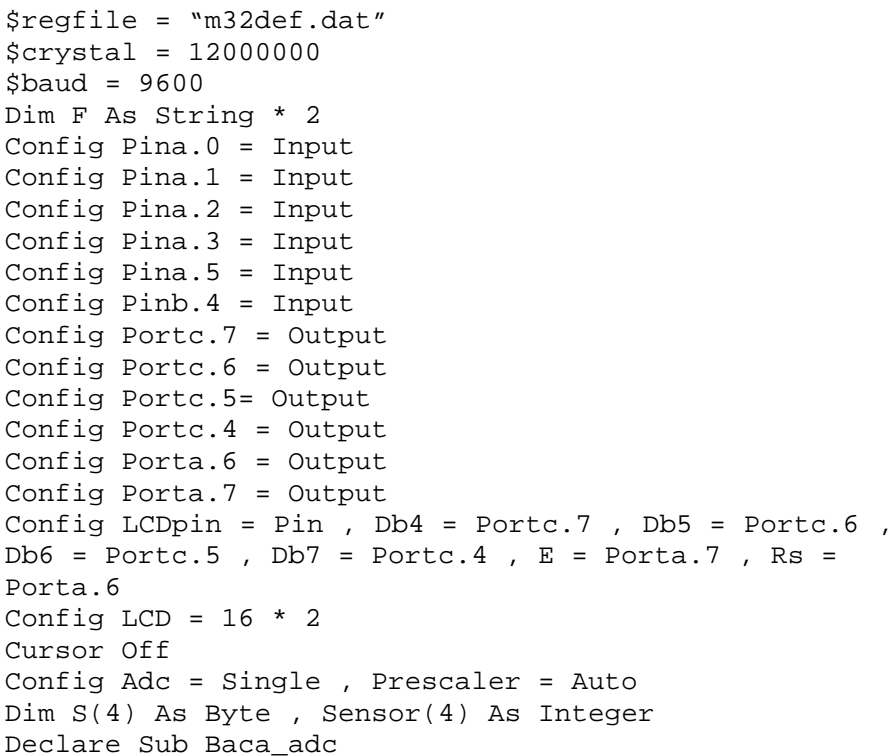

I Gede Pande Mastra Sedana:Sistem Kendali Otomatis Prototype ...
Berikut ini adalah listing program untuk pengujian sensor SRF04 yang terhubung ke sistem kontrol.

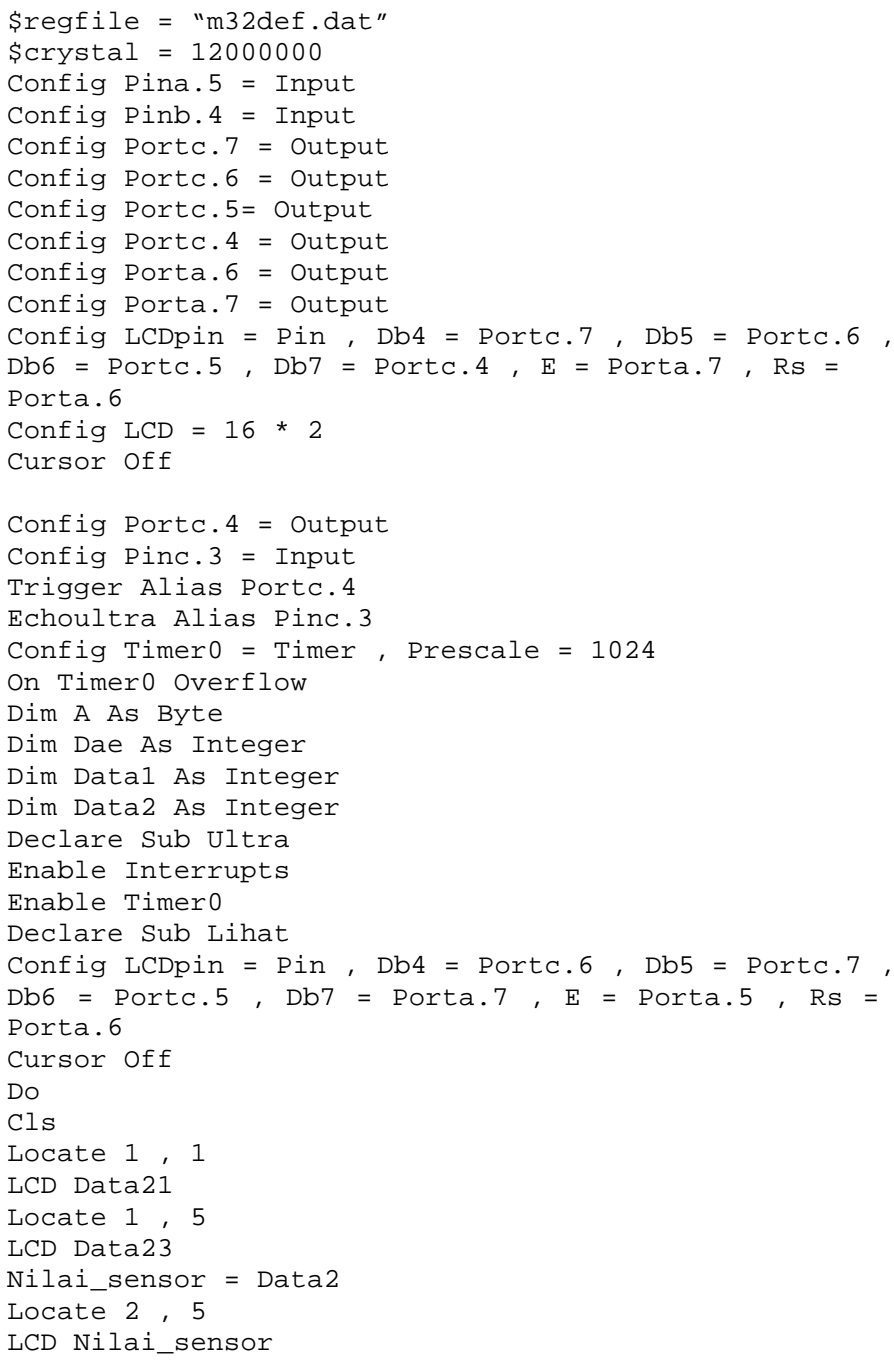


Call Ultra

Waitms 100

Loop

Tent $0=0$

$\mathrm{A}=0$

Dae $=0$

Data1 $=0$

Data2 $=0$

Reset Trigger

Waitus 10

Set Trigger

Waitus 10

Do

Loop Until Echoultra $=1$

Start Timer0

Do

If $\mathrm{A}>98$ Then

Stop Timer0

Data2 = 300

Goto Akhir

End If

Loop Until Echoultra $=0$

Stop Timer0

Dae $=$ Tcnto

Data1 $=A \star 256$

Data2 $=$ Data1 + Dae

Data2 $=$ Data2 $* 85$

Data2 = Data2 / 58

Akhir:

Waitus 10

End Sub

Overflow:

$\mathrm{A}=\mathrm{A}+1$

Return

Berikut ini merupakan listing program penamaan pin pada BASCOM AVR untuk sensor SRF-04

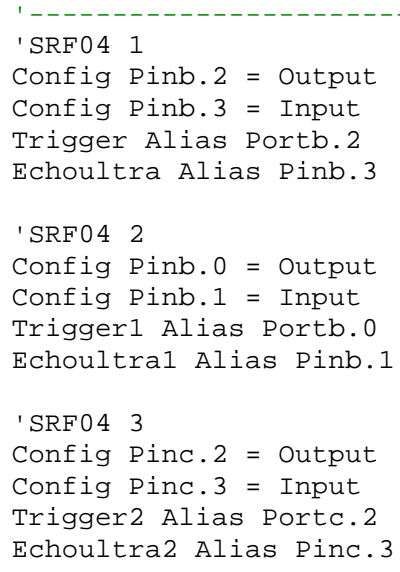

\section{H. Perancangan Sounder Robot Mobil}

Perancangan sound pada robot mobil bertujuan utnuk memberikan tanda peringatan apabila robot mencapai target tertentu. Ilustrasi sound pada robot ditunjukan oleh Gambar 20.
Sub Ultra:

Reset Trigger

Speaker

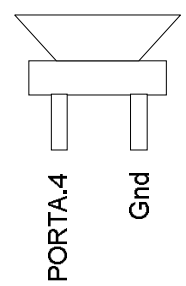

Gambar 20: Perancangan sounder robot mobil

Berikut ini merupakan listing program penamaan pin pada BASCOM AVR untuk sensor Sounder.

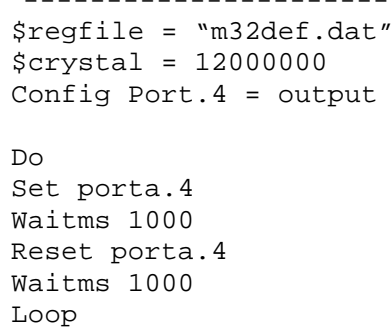

I. Perancangan Modul Wireless Bluetooth Robot Mobilc

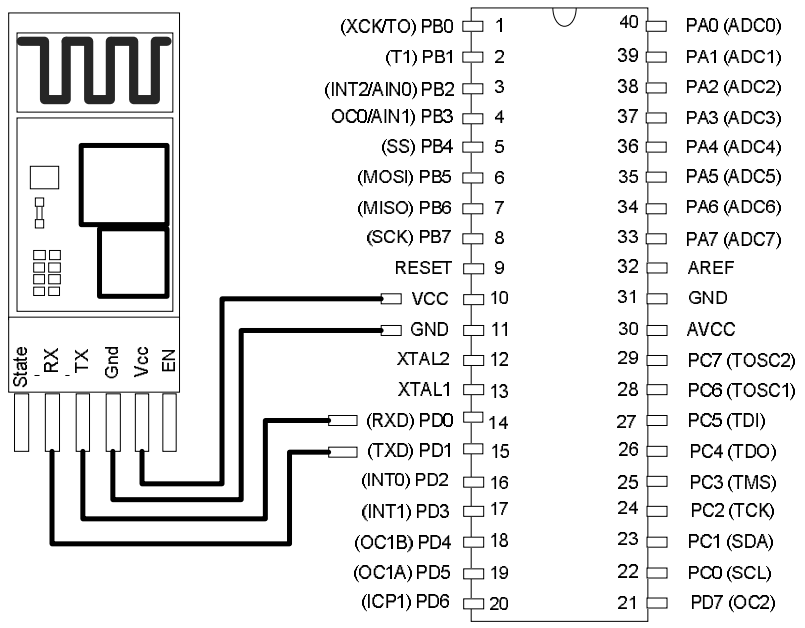

Gambar 21: Perancangan wireless bluetooth robot mobil

Berikut ini adalah listing program untuk pengujian Bluetooth HC-05 yang terhubung ke sistem kontrol.

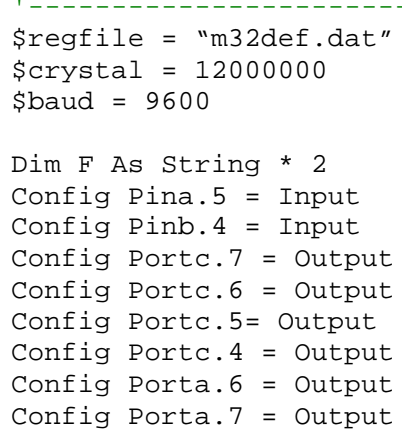


Config LCDpin $=$ Pin, Db4 = Portc. 7 , Db5 = Portc. 6 , $\mathrm{Db} 6=$ Portc. $5, \mathrm{Db} 7=$ Portc. $4, \mathrm{E}=$ Porta. $7, \mathrm{Rs}=$ Porta. 6

Config $\mathrm{LCD}=16 * 2$

Cursor off

Do

Locate 1,1

Lcd "Tes"

Print "Tes"

Waitms 100

loop

\section{HASIL DAN ANALISIS}

\section{A. Hasil Software Untuk Robot Mobil}

Tampilan software Pande Bluetooth Control untuk kendali robot mobil pada smartphone dapat dilihat pada Gambar 22.

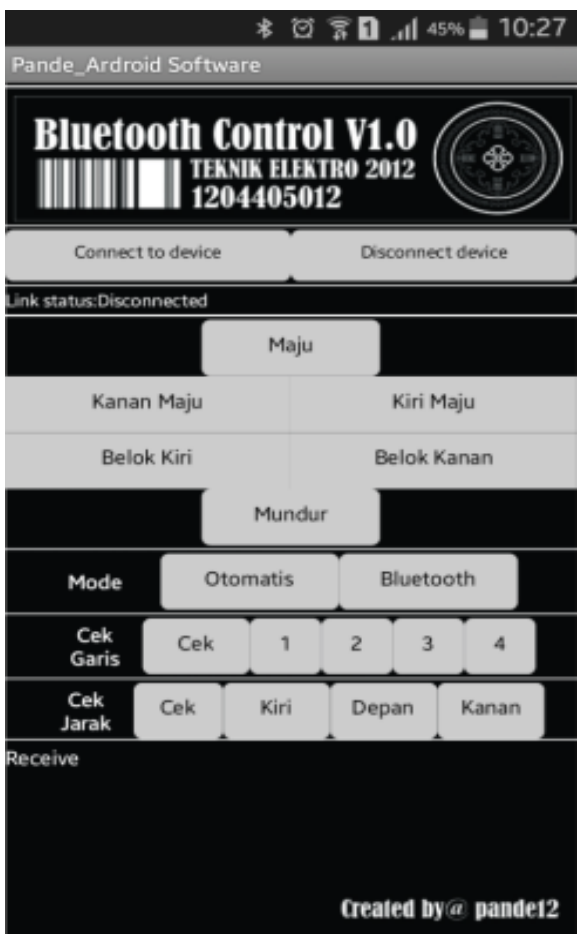

Gambar 22: Tampilan kendali robot mobil pada smartphone

Software dibuat agar dapat dijalankan di dalam smartphone tipe android yang memiliki fitur bluetooth. Software didesain untuk dapat mengirim dan menerima data secara bergantian. Masing-masing tombol yang terdapat pada tampilan kendali robot mobil memiliki penjelasan dan fungsi yang berbedabeda.

\section{B. Hasil Hardware Untuk Robot Mobil}

Tampilan Hardware untuk prototype sistem kendali otomatis robot mobil untuk parkir pintar menggunakan komunikasi nirkabel dapat dilihat pada Gambar 23.

I Gede Pande Mastra Sedana:Sistem Kendali Otomatis Prototype ..

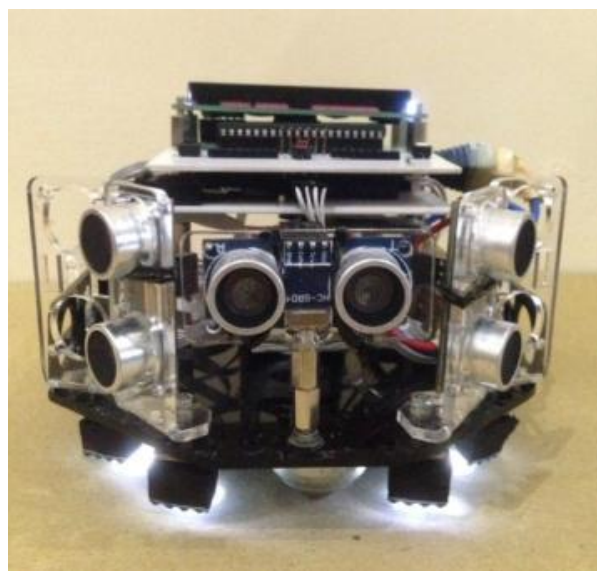

Gambar 23: Tampilan hardware robot mobil

Hardware dibuat agar dapat dijalankan di dalam lintasan yang memiliki permukaan datar. Hardware didesain untuk dapat mengirim dan menerima data secara bergantian. Masing-masing tombol yang terdapat pada robot mobil memiliki penjelasan dan fungsi yang berbeda-beda.

\section{Hasil Pengujian LCD Display}

Tujuan dari pengujian rangkaian LCD adalah untuk mengetahui apakah rangkaian LCD display yang dirancang dapat menampilkan informasi sesuai dengan yang telah direncanakan. Pengujian LCD tidak menggunakan alat ukur, tetapi langsung terhubung dengan mikrokontroler ATmega32 yang sebelumnya sudah diinputkan program pengujian. Hasil pengujian Lcd yang digunakan dapat dilihat pada Gambar 24.

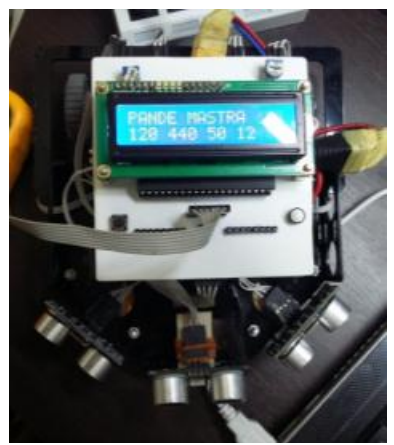

Gambar 24: Tampilan pengujian LCD robot mobil

Berdasarkan hasil pengujian rangkaian LCD display dengan mikrokontroler ATmega32, dapat dilihat bahwa rangkaian LCD display sudah dapat berkerja dengan baik sesuai dengan perencanaan.

\section{Hasil Pengujian Push Button}

Push button pada robot mobil berfungsi sebagai perantara fisik dalam memberikan inputan untuk mengendalikan robot mobil. Push button digunakan untuk memberikan perintah kepada mikrokontroller dengan membedakan nilai tegangan pada pin input mikrokontroler. Gambar 25 merupakan hasil pengujian push button ketika tidak ditekan, pengujian dilakukan dengan menggunakan voltmeter digital.

p-ISSN:1693 - 2951; e-ISSN: 2503-2372 


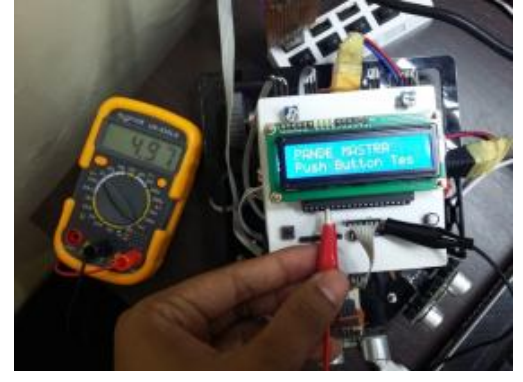

Gambar 25: Tampilan pengujian push button robot mobil

Hasil Pengujian push button pada saat ditekan dan tidak ditekan dapat dilihat pada Tabel 2.

TABEL III

HASIL PENGUJIAN PUSH BUTTON

\begin{tabular}{|c|c|c|c|c|}
\hline No & Pengujian & \multicolumn{2}{|c|}{ Nilai Tegangan } & Tampilan \\
\cline { 3 - 4 } & & Ditekan & Tidak & LCD \\
\hline 1 & Push Button 1 & $0.00 \mathrm{~V}$ & $4,97 \mathrm{~V}$ & "SW1" \\
\hline 2 & Push Button 2 & $0.00 \mathrm{~V}$ & $4,85 \mathrm{~V}$ & "SW2" \\
\hline
\end{tabular}

Ketika push button ditekan maka nilai tegangan akan menjadi 0V dan ketika push button tidak ditekan maka nilai tegangan yang didapatkan akan menjadi $5 \mathrm{~V}$.

\section{E. Hasil Pengujian Sensor Jarak}

Sensor jarak SRF04 digunakan sebanyak tiga buah, terletak pada bagian depan, bagian sisi kiri dan sisi kanan pada robot mobil yang langsung terhubung dengan mikrokontroler ATmega32. Sensor SRF04 berfungsi untuk mendeteksi adanya halangan. Gambar 26 merupakan hasil pengujian sensor jarak jenis SRF04.
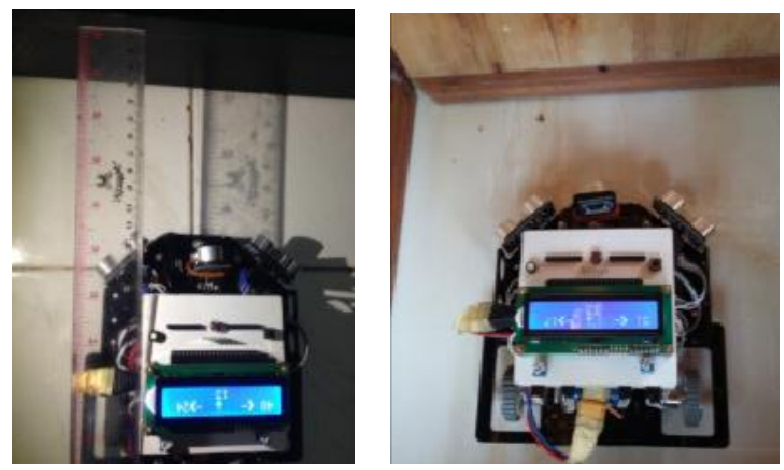

Gambar 26: Tampilan pengujian sensor jarak robot mobil

Hasil Pengujian dan pembacaan sensor jarak dapat dilihat pada Tabel 3.

TABEL IIIII

HASIL PENGUJIAN SENSOR JARAK

\begin{tabular}{|c|c|c|c|c|c|c|}
\hline \multirow{2}{*}{ No } & \multicolumn{2}{|c|}{ Pengukuran Penggaris (cm) } & \multicolumn{3}{c|}{ Pengukuran SRF-04 (cm) } \\
\cline { 2 - 7 } & Kiri & Depan & Kanan & Kiri & Depan & Kanan \\
\hline 1 & 3 & 3 & 3 & 3 & 3 & 3 \\
\hline 2 & 10 & 10 & 10 & 10 & 10 & 10 \\
\hline
\end{tabular}

\begin{tabular}{|c|c|c|c|c|c|c|}
\hline 3 & 20 & 20 & 20 & 19 & 19 & 19 \\
\hline 4 & 100 & 100 & 100 & 99 & 101 & 101 \\
\hline 5 & 160 & 160 & 160 & 158 & 161 & 160 \\
\hline 6 & 170 & 170 & 170 & 172 & 170 & 168 \\
\hline 7 & 200 & 200 & 200 & 196 & 198 & 196 \\
\hline 8 & 300 & 300 & 300 & 294 & 294 & 296 \\
\hline 9 & 345 & 345 & 345 & 342 & 343 & 345 \\
\hline 10 & 355 & 355 & 355 & 351 & 353 & 352 \\
\hline
\end{tabular}

Pengukuran dilakukan dengan membuat variasi jarak halangan terhadap robot mobil.

\section{F. Hasil Pengujian Sensor Garis}

Sensor garis pada pada robot mobil berfungsi sebagai pembaca garis parkir untuk robot mobil. Gambar 27 di bawah ini merupakan hasil pengujian sensor garis ketika mendeteksi warna terang di ditampilkan dalam bentuk ADC.

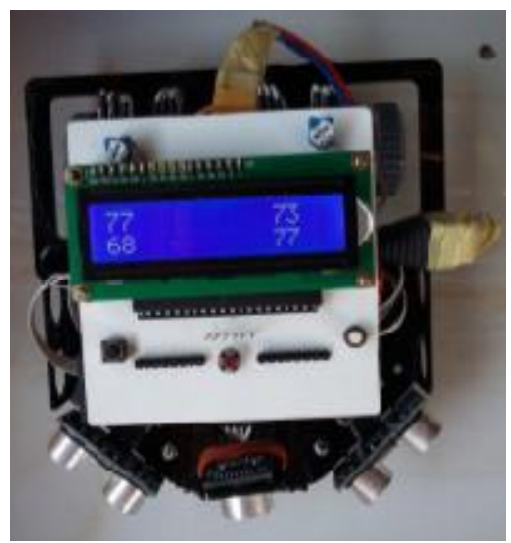

Gambar 27: Sensor garis mendeteksi warna terang

Gambar 27 menunjukan ke-empat buah sensor mendeteksi warna terang. Pada saat sensor mendeteksi warna terang sensor menunjukan hasil pembacaan di bawah 100. Hal ini dikarenakan pada saat cahaya terdeteksi terang iluminasi semakin tinggi, hambatan menjadi kecil sehingga arus yang mengalir semakin besar. Hasil Pengujian sensor garis terhadap beberapa warna dapat dilihat pada Tabel 4.

TABEL IVV

HASIL PENGUJIAN SENSOR JARAK

\begin{tabular}{|c|c|c|c|c|c|}
\hline \multirow{2}{*}{ No } & \multirow{2}{*}{ Warna } & \multicolumn{4}{|c|}{ Nilai ADC } \\
\cline { 3 - 6 } & & Sensor1 & Sensor2 & Sensor3 & Sensor4 \\
\hline 1 & Putih & 76 & 81 & 66 & 81 \\
\hline 2 & Hitam & 1023 & 1023 & 1023 & 1023 \\
\hline 3 & Coklat & 243 & 476 & 471 & 150 \\
\hline 4 & Biru Tua & 937 & 817 & 918 & 892 \\
\hline
\end{tabular}

\section{G. Hasil Pengujian Bluetooth}

Pengujian ATmega32 dengan smartphone ini dilakukan dengan menampilkan data yang diterima melalui LCD display yang terdapat pada robot mobil. Pengujian pengintegrasian ini akan dilakukan dengan mengirim data satu persatu dari smartphone ke dalam mikrokontroler ATmega32, dan sebaliknya data dari ATmega32 akan ditampilkan pada jendela hiperterminal smartphone user. 
Gambar 28 merupakan tampilan pengujian antara robot mobil dengan smartphone melalui aplikasi Arduino RC.

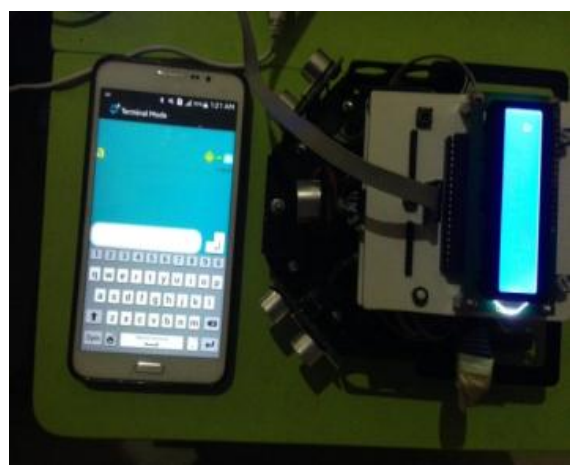

Gambar 28: Hasil pengujian bluetooth

Untuk pengujian karakter yang lainnya dirangkum dalam Tabel 5 dari pengujian diambil beberapa sample dari percobaan.

TABEL V

Hasil PENGUJiAn BLUETOOTH HC-05

\begin{tabular}{|c|c|c|c|}
\hline No & Data Hiperterminal & $\begin{array}{c}\text { Data Ditampilkan } \\
\text { LCD }\end{array}$ & Kecocokan \\
\hline 1 & A & A & Cocok \\
\hline 2 & B & B & Cocok \\
\hline 3 & C & C & Cocok \\
\hline 4 & D & E & Cocok \\
\hline 5 & E & F & Cocok \\
\hline 6 & F & G & Cocok \\
\hline 7 & G & H & Cocok \\
\hline 8 & H & 1 & Cocok \\
\hline 9 & 1 & 2 & Cocok \\
\hline 10 & 2 & 3 & Cocok \\
\hline 11 & 3 & 4 & Cocok \\
\hline 12 & 4 & 5 & Cocok \\
\hline 13 & 5 & 6 & Cocok \\
\hline 14 & 6 & 7 & Cocok \\
\hline 15 & 7 & 8 & Cocok \\
\hline 16 & 8 & 9 & Cocok \\
\hline 17 & 9 & & \\
\hline
\end{tabular}

\section{H. Hasil Pengujian Pergerakan Robot Secara Manual}

Pengujian pertama dilakukan tanpa adanya halangan di ruang lintasan. Pengujian dilakukan secara manual dengan menggunakan remote dari smartphone. Gambar 29 menunjukan simulasi pengujian di lintasan tanpa halangan.
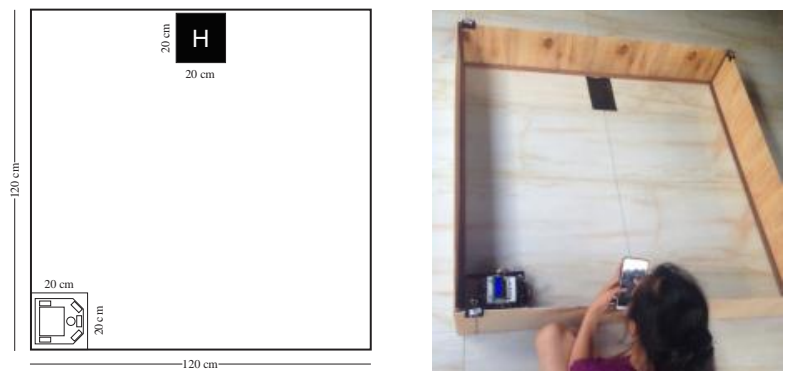

Gambar 29: Simulasi tanpa halangan
Percobaan pengujian dilakukan sebanyak 6 kali oleh dua user, Hasil pengujian dirangkum didalam Tabel 6 .

TABEL VI

Hasil Pengujian PercobaAn Manual Tanpa Halangan

\begin{tabular}{|c|c|c|}
\hline No & Waktu Tempuh & Akurasi Posisi \\
\hline Percobaan 1 & 21,04 Detik & Sampai di Tujuan \\
\hline Percobaan 2 & 14,04 Detik & Sampai di Tujuan \\
\hline Percobaan 3 & 7,70 Detik & Sampai di Tujuan \\
\hline Percobaan 4 & 11,99 Detik & Sampai di Tujuan \\
\hline Percobaan 5 & 10,30 Detik & Sampai di Tujuan \\
\hline Percobaan 6 & 11,02 Detik & Sampai di Tujuan \\
\hline
\end{tabular}

Diperoleh rata-rata waktu tempuh untuk percobaan manual tanpa adanya halangan yaitu 12,681 detik dengan waktu tempuh tercepat adalah 7,70 detik dan waktu tempuh terlama adalah 21,04 detik.

\section{Hasil Pengujian Pergerakan Robot Secara Otomatis}

1) Hasil Pengujian Pertama: Pengujian pergerakan robot mobil percobaan 1 saat parkir di lintasan tanpa halangan dapat dilihat pada Gambar 30.

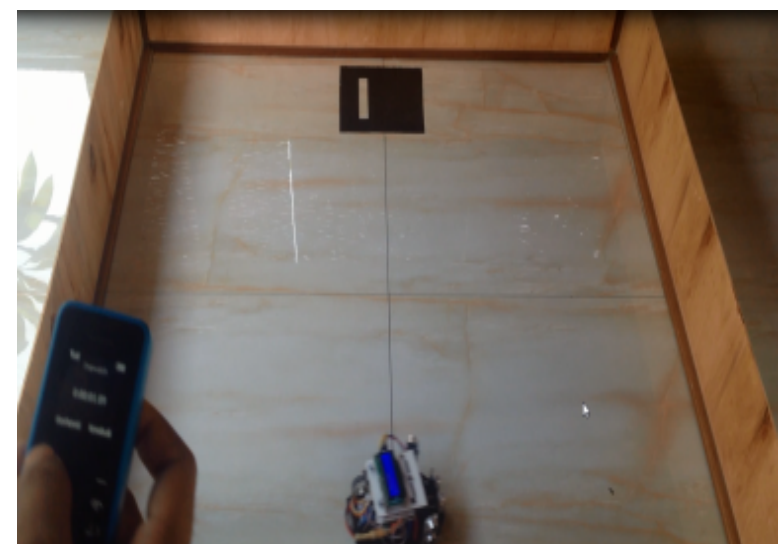

Gambar 30: Hasil pengujian percobaan mode otomatis 1

Percobaan pengujian dilakukan sebanyak 5 kali dan hasil pengujian dirangkum pada Tabel 7.

TABEL VII

HASIL PENGUJIAN PERGERAKAN ROBOT MOBIL PERCOBAAN 1

\begin{tabular}{|l|c|c|c|}
\hline No & Waktu Tempuh & Akurasi Posisi & Metode Telusur Robot \\
\hline 1 & 09,06 Detik & Sampai di Tujuan & Telusur Kanan \\
\hline 2 & 08,39 Detik & Sampai di Tujuan & Telusur Kanan \\
\hline 3 & 09,60 Detik & Sampai di Tujuan & Telusur Kanan \\
\hline 4 & 04,51 Detik & Sampai di Tujuan & Telusur Kiri \\
\hline 5 & 04,92 Detik & Sampai di Tujuan & Telusur Kiri \\
\hline
\end{tabular}

2) Hasil Pengujian Kedua: Pengujian akurasi posisi robot mobil percobaan 2 saat parkir di lintasan tanpa halangan dapat dilihat pada Gambar 31 .

I Gede Pande Mastra Sedana:Sistem Kendali Otomatis Prototype ... 


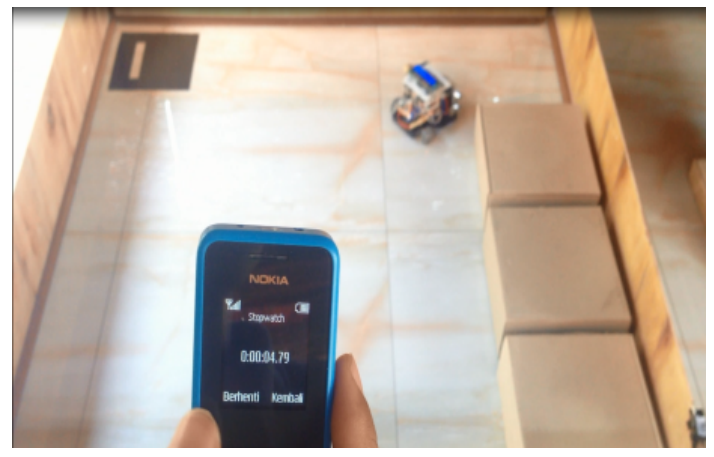

Gambar 31: Hasil pengujian percobaan mode otomatis 2

Percobaan pengujian dilakukan sebanyak 5 kali dan hasil pengujian dirangkum didalam Tabel 8.

TABEL VIII

HASIL PENGUJIAN PERGERAKAN ROBOT MOBIL PERCOBAAN 2

\begin{tabular}{|l|c|l|c|}
\hline No & $\begin{array}{c}\text { Waktu } \\
\text { Tempuh }\end{array}$ & Akurasi Posisi & $\begin{array}{c}\text { Metode Telusur } \\
\text { Robot }\end{array}$ \\
\hline 1 & 11,16 Detik & Sampai di Tujuan & Telusur Kanan \\
\hline 2 & 11,68 Detik & Sampai di Tujuan & Telusur Kanan \\
\hline 3 & 11,41 Detik & Sampai di Tujuan & Telusur Kanan \\
\hline 4 & 03,45 Detik & Sampai di Tujuan & Telusur Kiri \\
\hline 5 & 03,31 Detik & Sampai di Tujuan & Telusur Kiri \\
\hline
\end{tabular}

3) Hasil Pengujian Ketiga: Pengujian akurasi posisi robot mobil percobaan 3 saat parkir di lintasan tanpa halangan dapat dilihat pada Gambar 32.

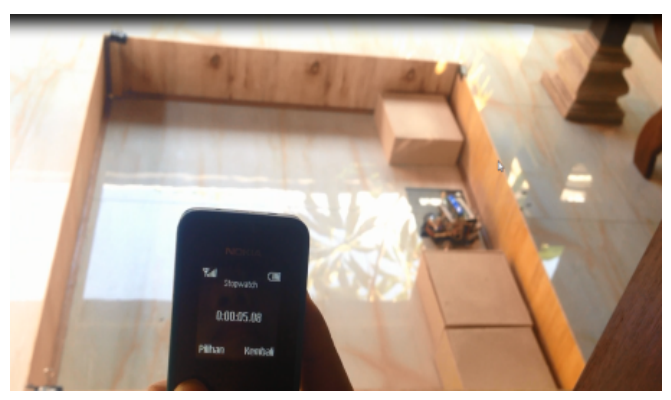

Gambar 32: Hasil pengujian percobaan mode otomatis 3

Percobaan pengujian dilakukan sebanyak 5 kali dan hasil pengujian dirangkum pada Tabel 9.

TABEL IX

HASIL PENGUJIAN PERGERAKAN ROBOT MOBIL PERCOBAAN 3

\begin{tabular}{|l|c|c|c|}
\hline No & $\begin{array}{c}\text { Waktu } \\
\text { Tempuh }\end{array}$ & Akurasi Posisi & $\begin{array}{c}\text { Metode Telusur } \\
\text { Robot }\end{array}$ \\
\hline 1 & 11,16 Detik & Sampai di Tujuan & Telusur Kanan \\
\hline 2 & 11,68 Detik & Sampai di Tujuan & Telusur Kanan \\
\hline 3 & 11,41 Detik & Sampai di Tujuan & Telusur Kanan \\
\hline 4 & 03,35 Detik & Sampai di Tujuan & Telusur Kiri \\
\hline 5 & 03,79 Detik & Sampai di Tujuan & Telusur Kiri \\
\hline
\end{tabular}

4) Hasil Pengujian Keempat: Pengujian akurasi posisi robot mobil percobaan 4 saat parkir di lintasan tanpa halangan dapat dilihat pada Gambar 33.

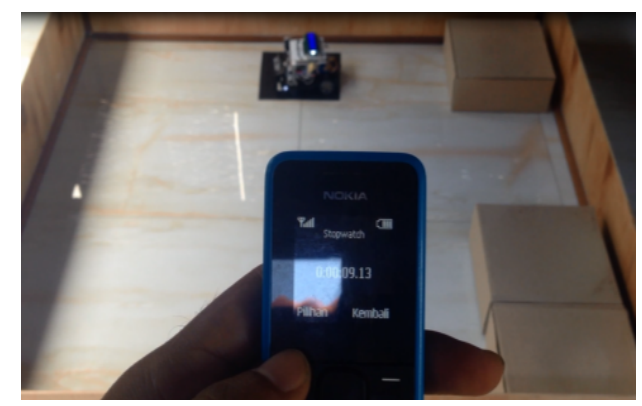

Gambar 33: Hasil pengujian percobaan mode otomatis 4

Percobaan pengujian dilakukan sebanyak 5 kali dan hasil pengujian dirangkum pada Tabel 10.

TABEL X

HASIL PENGUJIAN PERGERAKAN ROBOT MOBIL PERCOBAAN 4

\begin{tabular}{|c|c|c|c|}
\hline No & $\begin{array}{c}\text { Waktu } \\
\text { Tempuh }\end{array}$ & Akurasi Posisi & $\begin{array}{c}\text { Metode Telusur } \\
\text { Robot }\end{array}$ \\
\hline 1 & 09,13 Detik & Sampai di Tujuan & Telusur Kanan \\
\hline 2 & 09,13 Detik & Sampai di Tujuan & Telusur Kanan \\
\hline 3 & 10,22 Detik & Sampai di Tujuan & Telusur Kanan \\
\hline 4 & 03,86 Detik & Sampai di Tujuan & Telusur Kiri \\
\hline 5 & 03,94 Detik & Sampai di Tujuan & Telusur Kiri \\
\hline
\end{tabular}

5) Hasil Pengujian Kelima: Pengujian akurasi posisi robot mobil percobaan 5 saat parkir di lintasan tanpa halangan dapat dilihat pada Gambar 34.

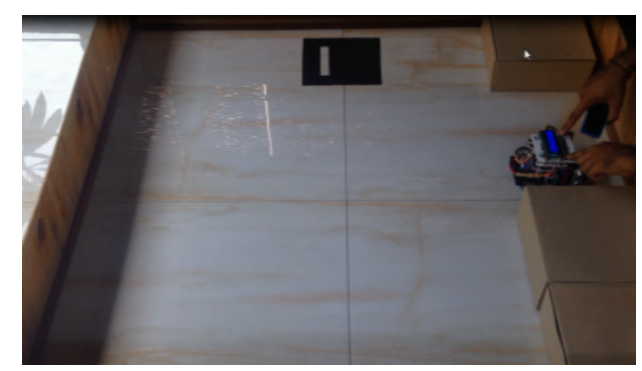

Gambar 34: Hasil pengujian percobaan mode otomatis 5

Percobaan pengujian dilakukan sebanyak 5 kali dan hasil pengujian dirangkum didalam Tabel 11.

TABEL XI

HASIL PENGUJIAN PERGERAKAN ROBOT MOBIL PERCOBAAN 5

\begin{tabular}{|l|c|c|c|}
\hline No & $\begin{array}{c}\text { Waktu } \\
\text { Tempuh }\end{array}$ & Akurasi Posisi & $\begin{array}{c}\text { Metode Telusur } \\
\text { Robot }\end{array}$ \\
\hline 1 & 04,18 Detik & Sampai di Tujuan & Telusur Kanan \\
\hline 2 & 04,51 Detik & Sampai di Tujuan & Telusur Kanan \\
\hline 3 & 04,24 Detik & Sampai di Tujuan & Telusur Kanan \\
\hline 4 & 09,50 Detik & Sampai di Tujuan & Telusur Kiri \\
\hline 5 & 08,30 Detik & Sampai di Tujuan & Telusur Kiri \\
\hline
\end{tabular}




\section{J. Hasil Pengujian Akurasi Posisi Robot}

Pengujian akurasi posisi robot mobil dilakukan untuk mengetahui persentase kesalahan pada saat robot mobil mencari posisi parkir.

Parkir dianggap berhasil apabila robot sudah berada pada posisi titik hitam yang dianggap tempat parkir. Percobaan yang dilakukan sebanyak 35 kali pada lintasan yang digunakan untuk menguji akurasi posisi dari robot mobil ketika parkir.

Dari percobaan yang sudah dilakukan, dapat dicari persentase kesalahan gesekan pada saat robot mobil menelusuri ruangan, dari 35 kali percobaan, robot mobil berhasil mendapatkan posisi tanpa ada gesekan sebanyak 30 kali dan 5 kali mengalami gesekan kecil dengan persentase untuk terjadinya gesekan adalah adalah $14.28 \%$.

Pergerakan robot pada saat simulasi pertama dan selanjutnya mengalami sedikit perbedaan pada saat robot berjalan, karena kecepatan putaran motor pada robot mobil dapat menjadi pengaruh didalam pergerakan motor DC pada robot mobil dalam menemukan tujuan parkir.

Hasil pengujian akurasi posisi robot mbil dapat dilihat pada Tabel 12.

TABEL XII

PENGUJIAN AKURASI POSISI ROBOT MOBIL DILAKUKAN 35 PERCOBAAN

\begin{tabular}{|c|c|c|c|c|}
\hline No & $\begin{array}{c}\text { Gesekan } \\
\text { Tembok }\end{array}$ & Posisi Parkir & $\begin{array}{l}\text { Posisi } \\
\text { Lurus }\end{array}$ & $\begin{array}{l}\text { Metode } \\
\text { Telusur }\end{array}$ \\
\hline 1 & Tidak Ada & Dalam Posisi Parkir & Lurus & Kiri \\
\hline 2 & Tidak Ada & Dalam Posisi Parkir & Lurus & Kiri \\
\hline 3 & Tidak Ada & Dalam Posisi Parkir & Lurus & Kiri \\
\hline 4 & Tidak Ada & Dalam Posisi Parkir & Lurus & Kiri \\
\hline 5 & Tidak Ada & Dalam Posisi Parkir & Lurus & Kiri \\
\hline 6 & Tidak Ada & Dalam Posisi Parkir & Lurus & Kiri \\
\hline 7 & Tidak Ada & Dalam Posisi Parkir & Lurus & Kanan \\
\hline 8 & Tidak Ada & Dalam Posisi Parkir & Lurus & Kanan \\
\hline 9 & Tidak Ada & Dalam Posisi Parkir & Lurus & Kanan \\
\hline 10 & Tidak Ada & Dalam Posisi Parkir & Lurus & Kanan \\
\hline 11 & Tidak Ada & Dalam Posisi Parkir & Lurus & Kanan \\
\hline 12 & Tidak Ada & Dalam Posisi Parkir & Lurus & Kanan \\
\hline 13 & Tidak Ada & Dalam Posisi Parkir & Lurus & Kanan \\
\hline 14 & Tidak Ada & Dalam Posisi Parkir & Lurus & Kanan \\
\hline 15 & Tidak Ada & Dalam Posisi Parkir & Lurus & Kanan \\
\hline 16 & Tidak Ada & Dalam Posisi Parkir & Lurus & Kanan \\
\hline 17 & Tidak Ada & Dalam Posisi Parkir & Lurus & Kanan \\
\hline 18 & Tidak Ada & Dalam Posisi Parkir & Lurus & Kanan \\
\hline 19 & Ada Gesekan & Dalam Posisi Parkir & Lurus & Kanan \\
\hline 20 & Tidak Ada & Dalam Posisi Parkir & Lurus & Kanan \\
\hline 21 & Tidak Ada & Dalam Posisi Parkir & Lurus & Kanan \\
\hline 22 & Tidak Ada & Dalam Posisi Parkir & Lurus & Kanan \\
\hline 23 & Tidak Ada & Dalam Posisi Parkir & Lurus & Kanan \\
\hline 24 & Tidak Ada & Dalam Posisi Parkir & Lurus & Kanan \\
\hline 25 & Ada Gesekan & Dalam Posisi Parkir & Lurus & Kanan \\
\hline 26 & Tidak Ada & Dalam Posisi Parkir & Lurus & Kanan \\
\hline 27 & Tidak Ada & Dalam Posisi Parkir & Lurus & Kanan \\
\hline 28 & Ada Gesekan & Diluar Posisi Parkir & Tidak Lurus & Kanan \\
\hline 29 & Ada Gesekan & Dalam Posisi Parkir & Lurus & Kanan \\
\hline 30 & Tidak Ada & Dalam Posisi Parkir & Lurus & Kanan \\
\hline 31 & Ada Gesekan & Dalam Posisi Parkir & Tidak Lurus & Kanan \\
\hline 32 & Tidak Ada & Dalam Posisi Parkir & Lurus & Kanan \\
\hline 33 & Tidak Ada & Dalam Posisi Parkir & Tidak Lurus & Kanan \\
\hline 34 & Tidak Ada & Dalam Posisi Parkir & Tidak Lurus & Kanan \\
\hline 35 & Ada Gesekan & Dalam Posisi Parkir & Lurus & Kanan \\
\hline
\end{tabular}

Dari percobaan yang sudah dilakukan, dapat dicari persentase kesalahan pada akurasi posisi parkir robot mobil, dari 35 kali percobaan, robot mobil berhasil mendapatkan posisi sebanyak 34 kali dan 1 kali melewati posisi tujuan dengan persentase untuk pencapaian posisi adalah $97.14 \%$.

Untuk posisi akurasi robot mobil dalam keadaan lurus dapat dicapai sebanyak 31 kali dan 4 kali tidak lurus, dengan persentase akurasi posisi robot mobil adalah mencapai yaitu $88.57 \%$.

\section{KESIMPULAN}

Simpulan yang dapat diambil berdasarkan hasil pengujian dan pembahasan yang telah dilakukan adalah sebagai berikut.

1. Robot mobil sudah dapat di integrasikan terhadap Smartphone melalui HC-05 yang terdapat pada ATmega32, komunikasi antara Robot Mobil dan Smartphone dilakukan dengan melakukan konfigurasi kristal dan baud rate pada program Basic Compiler AVR.

2. Pengintegrasian Atmega32 dengan sensor jarak dilakukan dengan memberikan sinyal pulsa high pada pin triger dari sensor untuk mengaktifkan sensor ultrasonik. Untuk menghitung lebar PWM sensor mengunakan timer0. Pin echo pulse output dari SRF04 terhubung dengan pin pada mikrokontroler. Ketika pin echo pulse output bernilai high maka timer0 aktif dan ketika pin echo kembali bernilai low maka timer0 dimatikan dan data TCNT0 diambil sebagai data jarak.

3. Pengintegrasian Atmega dengan Sensor Garis dengan fungsi $A D C$ (Analog to Digital Converter) yang berfungsi untuk mengkodekan tegangan sinyal analog waktu kontinu ke bentuk sederetan bit digital waktu diskrit sehingga sinyal tersebut dapat diolah oleh Mikrokontroler ATmega32.

4. Pengintegrasian Atmega32 dengan Motor Driver dilakukan dengan mengatur PWM atau Pulse Width Modulation pada program Basic Sompiler, modulasi pada PWM dilakukan dengan cara merubah lebar pulsa dari suatu pulsa data. PWM mempunyai gelombang frekuensi yang tetap namun Duty-Cycle yang bervariasi antara 0\%$100 \%$ dengan range $0-255$ pada program.

5. Akurasi posisi robot mobil jika dikendalikan manual akan sesuai dengan kehendak user dan jika dijalankan secara mode otomatis hasil posisi lurus yang didapatkan $88.57 \%$ sesuai tujuan parkir.

\section{UCAPAN TERIMA KASIH}

Ucapan terimakasih ditujukan kepada tim dosen pembimbing dari Jurusan Teknik Elektro dan Komputer Universitas Udayana dalam penyelesaian penelitian ini.

\section{REFERENSI}

[1] A, Winoto. 2008. Mikrokontroler AVR ATMega 8/32/16/8535 dan Pemrogramannnya dengan Bahasa $\mathrm{C}$ pada WinAVR. Bandung: Informatika.

[2] Adrianto, H. 2008. Pemrograman AVR ATmega16 Menggunakan Bahasa C (CodeVision AVR). Bandung : Informatika. 
[3] Anonim. 2016. DC IC L293D. www.elektronikadasar.web.id/komponen/driver-motor-dc-1293d. Diakses tanggal 23 Februari 2016.

[4] Anwar, Salwin; Desmiwarman; Nazaruddin, Nazris. 2010. Pemakaian Remote Control Tv Dengan Menggunakan Mikrokontroler At89s51 Sebagai Alat Pemutus Dan Penghubung Tegangan Kwh Meter 1 Phasa. Elektron: Vol 2 No. 2.

[5] Ardika, I Komang. 2013. "Perancangan Sistem Kendali Mobile Robot Jarak Jauh Menggunakan Wireless Xbee-Pro Series $160 \mathrm{Mw}$ Berbasis Mikrokontroler ATmega32" (tugas akhir). Denpasar: Universitas Udayana.

[6] B.Ranga Raju. 2014. ARM7 Microcontroller based Robot controlled by an Android mobile utilizing Bluetooth, IJIRT Vol. 1 Issue 8.

[7] Mubarok, Fajar. 2015. "Pengembangan Media Pembelajaran Berbasis Mobile Application Menggunakan App Inventor Pada Mata Pelajaran Mekanika Teknik Untuk Siswa Kelas X Studi Keahlian Tgb Smk Negeri 3 Yogyakarta". (tugas akhir). Yogyakarta: Universitas Negeri Yogyakarta.

[8] Pancev, I Gede Darko. 2014. "Implementasi Hand Motion Control Terhadap Pergerakan Quadcopter Robot Dengan Menggunakan Sensor Accelerometer ADXL335 Dan Wireless Xbee-Pro Series $160 \mathrm{~mW}$ Berbasis Mikrokontroler ATmega32". (tugas akhir). Denpasar: Universitas Udayana.

[9] Pandiangan, Johannes. 2007. "Perancangan Dan Penggunaan Photodioda Sebagai Sensor Penghindar Dinding Pada Robot Forklift". (tugas akhir). Medan: Universitas Sumatera Utara.

[10] Ritika P. 2014. Android Mobile Phone Controlled Bluetooth Robot Using 8051 Microcontroller . Vol. 2 Issue 7, July 2014 